\title{
Humans as Superorganisms: How Microbes, Viruses, Imprinted Genes, and Other Selfish Entities Shape Our Behavior
}

\author{
Peter Kramer and Paola Bressan \\ Department of General Psychology, University of Padua, Italy
}

\begin{abstract}
Psychologists and psychiatrists tend to be little aware that (a) microbes in our brains and guts are capable of altering our behavior; (b) viral DNA that was incorporated into our DNA millions of years ago is implicated in mental disorders; (c) many of us carry the cells of another human in our brains; and (d) under the regulation of viruslike elements, the paternally inherited and maternally inherited copies of some genes compete for domination in the offspring, on whom they have opposite physical and behavioral effects. This article provides a broad overview, aimed at a wide readership, of the consequences of our coexistence with these selfish entities. The overarching message is that we are not unitary individuals but superorganisms, built out of both human and nonhuman elements; it is their interaction that determines who we are.
\end{abstract}

\section{Keywords}

brain parasites, gut-brain axis, microbiota, endogenous viruses, chimerism, imprinted genes, human superorganism, human holobiont

You will be assimilated. Resistance is futile. -The Borg, Star Trek: The Next Generation

Unbeknownst to many people, our emotions, cognition, behavior, and mental health are influenced by a large number of entities that reside in our bodies while pursuing their own interests, which need not coincide with ours. Such selfish entities include microbes, viruses, foreign human cells, and imprinted genes regulated by viruslike elements. This article provides a broad overview, aimed at a wide readership, of the consequences of our coexistence with these entities. Its aim is to show that we are not unitary individuals in control of ourselves but rather "holobionts" or superorganisms-meant here as collections of human and nonhuman elements that are to varying degrees integrated and, in an incessant struggle, jointly define who we are.

In the science-fiction series Star Trek, cyborgs (cybernetic organisms-part machine, part organism) of various different species are (wirelessly) interconnected and function as one "collective," a superorganism. The Borg, as they are called, forcibly assimilate new species into the collective, and this changes the behavior not only of these species but also of the collective itself. In real life- with the rudimentary exception of the few people whose brains directly connect to a visual aid or robotic limb or contain electronic implants to combat, for example, Parkinson's disease or depression (see Donoghue, 2002; also Bewernick et al., 2010; Collinger et al., 2013) - humans are not cyborgs. Still, the collective in which the Borg are incorporated can be seen as a metaphor for human nature. The point of this article is that, like this collective, we are not unitary individuals but superorganisms; and like the behavior of this collective, our behavior is altered by the many different entities (including hundreds of other species) that have, to various degrees, become integrated with us.

Figure 1 illustrates the nature of these entities and the routes through which they invade us. They will be introduced in the next five sections roughly in order oftheir increasing assimilation with our human components (Table 1); animal and physiological data will be discussed wherever they help place human psychological data into their proper context. This work integrates and 
complements other, usually more technical, reviews that focus on just one, or a relatively small class, of these entities.

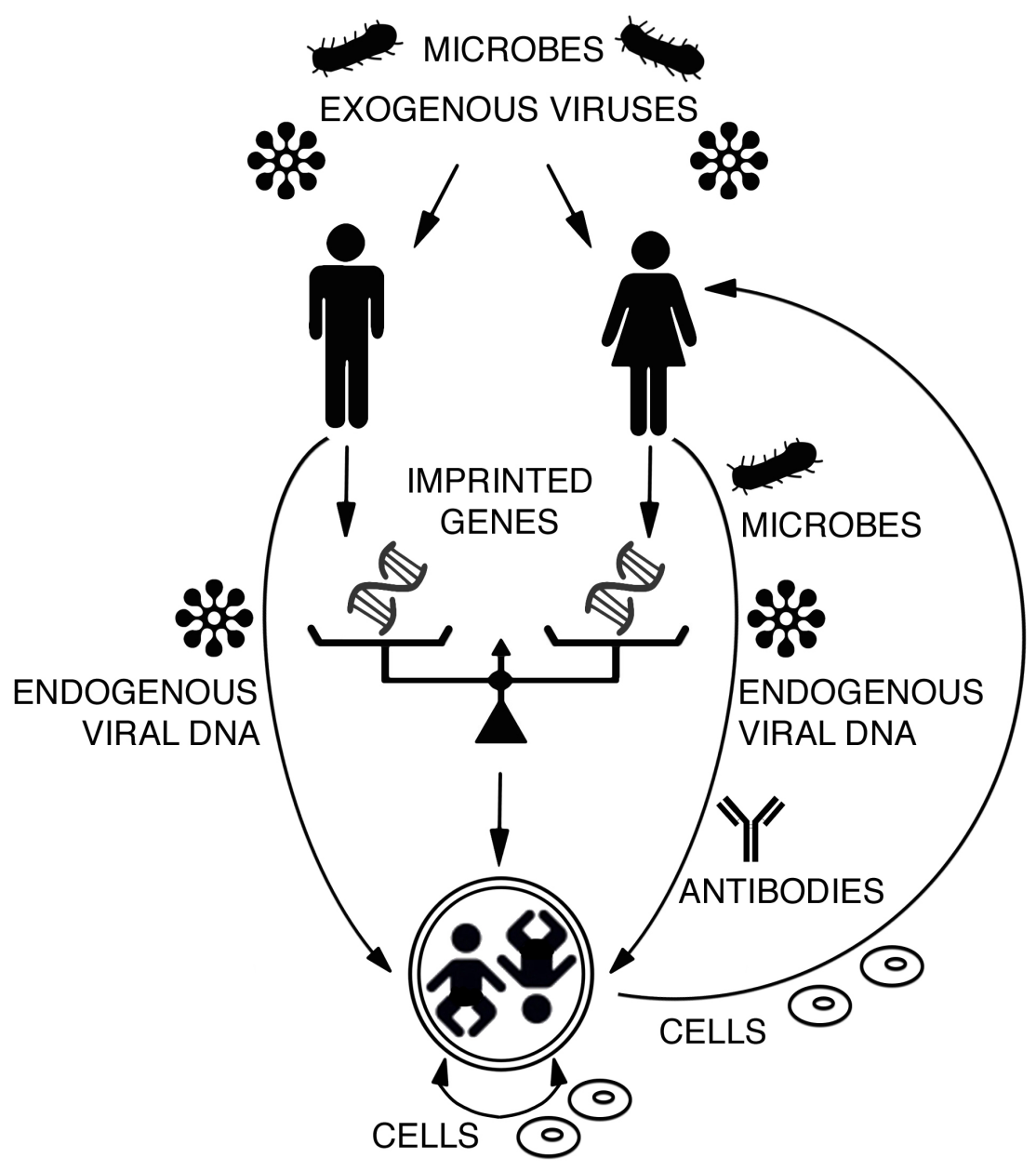

Fig. 1. Modes of invasion of humans by selfish entities. Top: Microbes (both gut bacteria and brain parasites) and exogenous viruses are ingested or inhaled. Middle: Imprinted genes and endogenous viral DNA are passed from parents to offspring (here represented as twin fetuses inside a womb). The effects of the paternally and maternally imprinted genes need to be in balance (which is why the double helices are depicted on a scale) for offspring to develop normally. Middle right: Microbes (both gut bacteria and some brain parasites) and antibodies from the mother invade the offspring (downward arrow), and cells from the offspring invade the mother (upward arrow). Bottom (double arrow): prenatal exchange of cells between offspring that start off as twins.

\section{Brain Microbes}

Some microbes have specialized in colonizing the brain of larger animals (euphemistically called hosts); from there, they can affect their victims' behavior. Because they do a disservice to their hosts, these microbes are parasites-creatures that exploit other creatures. Our exposure to them soared when, with the agricultural revolution, the beginning of animal domestication, and the accompanying urbanization some 10,000 years ago, we radically increased both in number and in proximity to one another and other animals (for a review, see Thomas, Daoust, \& Raymond, 2012).

Many parasitic microbes may take up temporary or permanent residence in our brain (for an extensive list, see Finsterer \& Auer, 2013), but the most instructive of the lot is Toxoplasma gondii. This unicellular organism is interesting not only because it is arguably capable of actively 
manipulating, rather than just influencing, the behavior of at least one of its hosts (the rat); and not only because a fair amount is known about the exact mechanisms behind its effects; but also because sooner or later-on occasion, with potentially serious consequences for our mental health-it will infect about half, or even most, of us (as found, respectively, in the United Kingdom and in the Netherlands: Walker, Nokes, \& Jennings, 1992; Kortbeek, 1999).

Brain microbes are the least integrated among the entities reviewed here. They are typically forced to alternate their life stages between different host species, such as humans and dogs; Toxoplasma passes from cats to rodents and back again and possibly infects humans only accidentally. Yet copies of these parasites remain lodged within us for the rest of our lives and keep interacting with our nervous system all along. Brain microbes thus effectively become part of the human superorganism; our behavior can be seen as guided no longer by a single evolutionary strategy but by separate human and microbial ones. This might indeed be one of the reasons why we sometimes engage in conduct that does not promote our own fitness (i.e., reproductive success) or even our immediate survival.

\begin{tabular}{|c|c|c|c|c|c|}
\hline Entity & $\begin{array}{l}\text { Assimilation } \\
\text { with human } \\
\text { components }\end{array}$ & Presence probability & $\begin{array}{l}\text { Continuity of } \\
\text { interaction }\end{array}$ & $\begin{array}{c}\text { Associated } \\
\text { physiological changes }\end{array}$ & $\begin{array}{l}\text { Associated behavioral } \\
\text { changes }\end{array}$ \\
\hline $\begin{array}{l}\text { Brain } \\
\text { microbes }\end{array}$ & $\begin{array}{l}\text { Incomplete } \\
\text { (interacting but } \\
\text { separable) }\end{array}$ & $\begin{array}{l}\text { Toxoplasma gondii: } \\
10 \%-70 \% \text { worldwide, } \\
\text { depending on age }\end{array}$ & $\begin{array}{l}\text { Potentially } \\
\text { lifelong }\end{array}$ & $\begin{array}{l}\text { Toxoplasma gondii: } \\
\text { tryptophan } \\
\text { breakdown, } \\
\text { dopamine increase }\end{array}$ & $\begin{array}{l}\text { Toxoplasma gondii: } \\
\text { reckless behavior, } \\
\text { depression, bipolar, and } \\
\text { obsessive-compulsive } \\
\text { disorders, schizophrenia }\end{array}$ \\
\hline $\begin{array}{l}\text { Gut } \\
\text { microbes }\end{array}$ & $\begin{array}{l}\text { Incomplete } \\
\text { (interacting but } \\
\text { separable) }\end{array}$ & $\begin{array}{l}100 \% \text { for certain } \\
\text { strains }\end{array}$ & $\begin{array}{l}\text { Lifelong for } \\
\text { certain strains }\end{array}$ & $\begin{array}{l}\text { Some strains: increase } \\
\text { in GABA and } \\
\text { other neuroactive } \\
\text { substances, cortisol } \\
\text { decrease }\end{array}$ & $\begin{array}{l}\text { Some strains: improvement } \\
\text { in depression and } \\
\text { anxiety symptoms }\end{array}$ \\
\hline $\begin{array}{l}\text { Exogenous } \\
\text { viruses }\end{array}$ & $\begin{array}{l}\text { Incomplete } \\
\text { (interacting but } \\
\text { separable) }\end{array}$ & $\begin{array}{l}\text { Cytomegalovirus: } \\
60 \%-90 \% \text { in the } \\
\text { United States, } \\
\text { depending on age }\end{array}$ & $\begin{array}{l}\text { Potentially } \\
\text { lifelong }\end{array}$ & $\begin{array}{l}\text { Interaction with host } \\
\text { genes }\end{array}$ & $\begin{array}{l}\text { Maternal cytomegalovirus: } \\
\text { schizophrenia in carriers } \\
\text { of common gene variant }\end{array}$ \\
\hline $\begin{array}{l}\text { Endogenous } \\
\text { viruses }\end{array}$ & $\begin{array}{l}\text { Complete for viral } \\
\text { DNA embedded } \\
\text { within our own } \\
\text { DNA }\end{array}$ & $\begin{array}{l}100 \% \text { for viral DNA } \\
\text { embedded within } \\
\text { our own DNA }\end{array}$ & $\begin{array}{l}\text { Lifelong for viral } \\
\text { DNA embedded } \\
\text { within our own } \\
\text { DNA }\end{array}$ & $\begin{array}{l}\text { If reactivated by } \\
\text { common pathogens: } \\
\text { neuroinflammation }\end{array}$ & $\begin{array}{l}\text { If reactivated by common } \\
\text { pathogens: bipolar } \\
\text { disorder, schizophrenia }\end{array}$ \\
\hline $\begin{array}{l}\text { Foreign } \\
\text { human } \\
\text { cells }\end{array}$ & Complete & $\begin{array}{l}\text { Embryonic or fetal male } \\
\text { cells inside mother's } \\
\text { and/or female co- } \\
\text { twin's brain: } 63 \%\end{array}$ & $\begin{array}{l}\text { Potentially } \\
\text { lifelong }\end{array}$ & $\begin{array}{l}\text { Maternal antibodies: } \\
\text { disruption of fetal } \\
\text { brain development }\end{array}$ & $\begin{array}{l}\text { Maternal antibodies: } \\
\text { neurodevelopmental } \\
\text { disorders (e.g., autism, } \\
\text { dyslexia) }\end{array}$ \\
\hline $\begin{array}{l}\text { Imprinted } \\
\text { genes }\end{array}$ & Complete & $100 \%$ & Lifelong & $\begin{array}{l}\text { Dysregulation: } \\
\text { various symptoms } \\
\text { of overgrowth or } \\
\text { undergrowth }\end{array}$ & $\begin{array}{l}\text { Dysregulation: autism- or } \\
\text { psychosis-spectrum } \\
\text { disorders }\end{array}$ \\
\hline
\end{tabular}

\section{Toxoplasma gondii}

Toxoplasma starts its life cycle as an egg inside the intestines of a cat (or another feline); rats and mice habitually feed on the cat's excrement and may ingest the eggs. In the intestines of these intermediate hosts, the eggs develop into highly active parasites that reproduce asexually and invade most of the animal's body and brain. The host's immune system can keep the parasites more or less in check but cannot eliminate them, because, when it kicks in, the parasites protect themselves by retreating into cysts, in a semidormant form (for a review, see Webster, Kaushik, Bristow, \& McConkey, 2013). Yet only if the intermediate host (typically a rat) is eventually consumed by the final host (typically a cat) can the parasites reproduce sexually, rather than asexually, inside the latter's intestines and lay eggs. It is generally accepted (but see Worth, Lymbery, \& Thompson, 2013) that Toxoplasma manipulates the brain of the rat so as to increase the probability that its otherwise uncertain transfer to the cat's intestines actually takes place. A rat with Toxoplasma in its brain loses its innate fear of cats and can even become sexually attracted to the odor of their urine (for reviews, see Flegr, 2013; McConkey, Martin, Bristow, \& Webster, 2013; Webster et al., 2013). 
Mammals, birds, and fish that consume infected animals or ingest contaminated water get infected, too. Eating their meat undercooked is by far the most typical, though not the only (for a review, see Tenter, Heckeroth, \& Weiss, 2000), way of contracting the parasite for us; according to one study, $38 \%$ of British commercial meat is contaminated (Aspinall, Marlee, Hyde, \& Sims, 2002). No wonder Toxoplasma infection is extremely common, ranging, in women of childbearing age, from about $10 \%$ in countries with religions that promote vegetarianism, such as Thailand, Vietnam, or South Korea, to $50 \%$ in some developed European nations and over $70 \%$ in some parts of Africa and Latin America (Flegr, Prandota, Sovic `ková, \& Israili, 2014; Tenter et al., 2000).

\section{Toxoplasma's effect on human behavior}

Toxoplasma's sexual reproduction requires that its intermediate host stays alive until caught by a cat and that the cat stays alive until the parasite's eggs are excreted. Consistently, Toxoplasma's impact on the physical health of its hosts is typically benign. Its effects on their mental health, though, are another matter. In humans, the infection has been associated with workplace and traffic accidents (possibly because it renders one less careful and slows down reaction time), depression, suicides, changes in personality, and various mental and neurological diseases, including bipolar and obsessive-compulsive disorders (for reviews, see Fabiani, Pinto, \& Bruschi, 2013; Flegr, 2013; Hurley \& Taber, 2012; Hsu, Groer, \& Beckie, 2014). In particular, Toxoplasma infection raises the probability of developing schizophrenia 2.7 times and is thereby the largest known single risk factor of the disorder- larger than any of the currently known genetic and environmental ones (for a meta-analysis, see Torrey, Bartko, Lun, \& Yolken, 2007).

Various findings suggest that Toxoplasma infection not only correlates with particular human behaviors but actually causes, or at least precedes, them (for a review, see Flegr, 2013). For example, a study on 180 soldiers who were discharged from the American army with a diagnosis of schizophrenia discovered that schizophrenia was predicted by Toxoplasma antibodies (evidence of infection) not only in blood samples taken after diagnosis but also in those taken in a period from just before the diagnosis to up to six months earlier (Niebuhr et al., 2008).

\section{Mechanisms of Toxoplasma's integration in the human superorganism}

A possible mechanism for how Toxoplasma interacts with us-for example, causing schizophrenia-relies on the fact that, in the presence of the parasite, we mount an immune response that breaks down the amino acid tryptophan. Neurochemical changes that typically result from the breakdown of tryptophan have been observed in the brains of schizophrenia patients and are implicated (for reviews, see Müller, Myint, \& Schwarz, 2011; Wonodi \& Schwarcz, 2010) in schizophrenia-associated deficits in perception, spatial working memory, contextual learning, and prepulse inhibition (the attenuation of a startle reflex to a strong stimulus by prior adaptation to a weaker one). Tryptophan breakdown also antagonizes NMDA receptors (which are involved in synaptic plasticity, learning, and memory), up-regulating the dopamine system (for reviews, see Flegr, 2013; Müller et al., 2011; Wonodi \& Schwarcz, 2010). On top of that, Toxoplasma directly synthesizes an enzyme that can increase the host's dopamine production even further (Gaskell, Smith, Pinney, Westhead, \& McConkey, 2009). Indeed, in vitro, dopamine release has been found to be seven times larger in Toxoplasma-infected mouse cells than in uninfected ones; in vivo, the effect is estimated to be larger still (Prandovszky et al., 2011; for discussion of related evidence, see McConkey et al., 2013).

Up-regulation of the dopamine system has been associated with both reckless sensation seeking (e.g., Norbury, Manohar, Rogers, \& Husain, 2013) and positive schizophrenia symptoms (for a review, see Kantrowitz \& Javitt, 2010). It is interesting to note that common antipsychotic drugs that target the dopamine system, such as haloperidol and valproic acid, inhibit Toxoplasma's replication and ability to invade brain cells (Jones-Brando, Torrey, \& Yolken, 2003; Webster, Lamberton, Donnelly, \& Torrey, 2006), suggesting that (some of) the effect of these drugs may be due to their antiparasitic properties. 


\section{Gut Microbes}

Unlike brain microbes, gut microbes do not reside in the brain; still, it is becoming increasingly evident that they affect both the brain and our behavior. The human gastrointestinal tract houses up to 100 trillion microorganisms, belonging to more than 7,000 strains; collectively, these contain 10 times the number of human cells and 100 times as many genes as our genome (for a review, see Ley, Peterson, \& Gordon, 2006). Each of us harbors at least 160 bacterial species, many of which are shared among us but in wildly different proportions (Qin et al., 2010), allowing for considerable interpersonal differences. Colonization begins before birth (Funkhouser \& Bordenstein, 2013) and receives abundant supplementation as we travel through our mother's birth canal-which imparts to the initial microbiota a maternal signature; by the end of the first year of life, however, every baby has a distinct, adultlike microbial ecosystem (Palmer, Bik, DiGiulio, Relman, \& Brown, 2007). It is telling that the high vulnerability of newborns to infections appears to be favored by specific red cells in their blood; these actively suppress babies' immune system so that bacteria can safely colonize their gut (Elahi et al., 2013). The high cost (decreased resistance to pathogens) of having evolved this response suggests that being colonized benefits us as much as it does the microbes. Thus, nonhuman gut microbes likely represent an ancient, stable, fundamental component of the human superorganism.

Indeed, the process of bacterial colonization initiates signaling mechanisms that irreversibly affect behavior, by both turning genes on or off and altering the communication between neurons in specific brain regions. In animals, the evidence is overwhelming. For example, mice that have been raised so that their gut remains (virtually) germ free show, when unstressed, lower anxiety than normal mice (Diaz Heijtz et al., 2011; Neufeld, Kang, Bienenstock, \& Foster, 2011)—which might be interpreted as increased risk taking, with its attendant dangers (Bested, Logan, \& Selhub, 2013). However, the endocrine reaction of germ-free animals to acute stress (remaining confined for $1 \mathrm{hr}$ inside a tiny conical tube) is abnormally large. Such altered stress response is partly corrected if these animals are inoculated with the fresh feces of normal mice in their adolescence but cannot be reversed later than that (Sudo et al., 2004). Thus, early exposure to (healthy) gut flora is required for normal development of the stress response. Some studies (e.g., Shanks et al., 2000) suggest that neonatal infection with pathological bacteria may permanently alter such response, predisposing the individual to stress-related disorders later in life.

The repercussions of microbiota involvement in behavioral repertoires that we would, ordinarily, ascribe to personality can be quite disconcerting. If germ-free mice are colonized with gut bacteria from their own strain, their subsequent behavior is typical of that strain. If, however, they are colonized with gut bacteria from a different strain, they behave like the donor strain (Bercik et al., 2011): Timid mice become adventurous, and adventurous mice become timid. Fecal bacteria transplants between people are occasionally carried out as last-resort interventions to displace pathogenic microorganisms in some gastrointestinal disorders, with healing rates over 90\% (Gough, Shaikh, \& Manges, 2011). Interestingly, although controlled studies are still lacking, there are anecdotal reports of a decrease in neurological symptoms in patients with Parkinson's disease and of improvements in insomnia and major depression following such procedures (Borody, Paramsothy, \& Agrawal, 2013).

\section{Mechanisms of gut microbiota's integration in the human superorganism}

Considering that the gastrointestinal tract is currently estimated to contain at least 500 million neurons (Furness, 2006), that gut microbiota and brain can talk to one another hardly comes as a surprise. Yet, how the communication between gut microbiota and brain occurs is not fully understood; not only neural but also endocrine and immune mechanisms have been proposed and in some cases established (for a review, see Cryan \& Dinan, 2012).

Bacteria are capable of modulating gastrointestinal inflammation, and chronic, low-grade inflammation has been implicated in schizophrenia (Severance et al., 2012) and in mood disturbances, notably anxiety (Bercik et al., 2010) and depression (for a review, see Dantzer, O'Connor, Freund, Johnson, \& Kelley, 2008). However, inflammation is not required for gut bacteria to affect the brain (Lyte, Varcoe, \& Bailey, 1998).

The composition of the gut microbiota can change not only following invasions of bacteria from 
the outside world (typically through the mouth) but also as a result of internal wars among competing strains. Several studies suggest that the fate of these hostilities is influenced by the host's psychological state and influences it in turn. In humans, emotional stress reduces the representation of beneficial variants such as bifidobacteria and lactobacilli (e.g., Lizko, 1987) and thus creates more room for the expansion of detrimental ones. The metabolic end products of some of the latter, such as clostridia, increase social isolation in rats (Shultz et al., 2008) and have been linked to autism-spectrum disorders (Shultz et al., 2008; Song, Liu, \& Finegold, 2004); clostridia are often overrepresented in the guts of children with autism (for a review, see Louis, 2012). In fact, the putative psychological benefits of yogurt might partly result from the temporary displacement of deleterious strains by the bifidobacteria and lactobacilli that yogurt contains.

\section{Yogurt and the brain}

Further supporting the idea that the microbiota plays a causal role in the well-being of its host is recent documentation that some mood disturbances can be mitigated by ingesting probiotics (microorganisms whose consumption provides health benefits, typically bifidobacteria and lactobacilli). Again, the evidence provided by animal trials is impressive. In adult rats, for example, Bifidobacterium infantis reduces-although not as much as a commonly prescribed antidepressant-the despair-like behaviors that ensue from early maternal separation (such as simply keeping afloat, without attempting to swim or climb, when placed in a jug of water; Desbonnet et al., 2010). Again in mice, drinking a broth containing lactobacilli (as opposed to plain broth) once a day for one month diminishes anxiety- and depression-like behaviors and improves memory while modulating the expression of the GABA receptor; partial removal of the vagus-an important nerve that carries sensorial information from several organs, including stomach and intestines, up to the brain—cancels these effects (Bravo et al., 2011).

GABA is the prime inhibitory neurotransmitter in humans, and its dysregulation is implicated in both anxiety and depression, which are highly comorbid with bowel disorders (Gros, Antony, McCabe, \& Swinson, 2009); antianxiety drugs such as benzodiazepines target GABA receptors. Several probiotic bacteria (called "psychobiotics" by Dinan, Stanton, \& Cryan, 2013) are capable of manufacturing and releasing GABA and other neuroactive substances, including noradrenaline, acetylcholine, serotonin, and dopamine. This suggests still another pathway through which probiotics could influence the brain.

In humans, the evidence for the psychological benefits of probiotics is still sparse. Lactobacilli have been reported to decrease anxiety (though not depression) symptoms in patients suffering from chronic fatigue syndrome (Rao et al., 2009). In stressed volunteers, daily consumption of a probiotic formulation for 3 weeks improved gastrointestinal distress but not "psychological symptoms" (Diop, Guillou, \& Durand, 2008). Yet in healthy individuals, 1 month of the same probiotic formulation did reduce self-reported anxiety and depression, along with cortisol levels, showing the same efficacy as benzodiazepines (Messaoudi et al., 2011). One recent study went beyond self-ratings, showing that probiotics modify healthy women's brain activity in regions that control processing of emotion and sensation, dampening reactions to facial expressions of anger and fear (Tillisch et al., 2013); these same regions are involved in anxiety disorders (Paulus \& Stein, 2006).

Perhaps unsurprising at this point of the story, one study found that a 7-day course of antibiotics, which heavily perturb the bacterial composition of the gut, altered brain chemistry and exploratory behavior in normal but not in germ-free mice (Bercik et al., 2011). In humans, the antibiotic minocycline has repeatedly been shown to improve depression symptoms, either alone or in combination with antidepressants (for reviews, see Pae, Marks, Han, \& Patkar, 2008; Soczynska et al., 2012) or probiotics (references in Bested et al., 2013). These effects are evidently due to the modulation of the microbial components of our superorganism.

\section{Brain Viruses}

Brain and gut microbes are living creatures. Whether viruses can be considered as such continues to be debated. There is little doubt, however, that they are particularly competent 
invaders of both bodies and brains; and that they not only affect but can also manipulate the behavior of some of their hosts (e.g., Hoover et al., 2011).

Viruses consist of strands of either RNA or DNA, encapsulated within a protein shell together with the enzymes necessary for their reproduction. The host's cell is tricked into absorbing this capsule, which inside the cell releases its contents. As we shall see, whereas exogenous viruses (those of external origin) simply infect individuals and cease their activity before or with these individuals' death, some viruses have become endogenous (of internal origin) by incorporating their own DNA into that of their hosts in cells that give rise to sperm or eggs. The DNA of these viruses is thus transmitted across all subsequent generations of their hosts, having effectively become an integral part of them.

\section{Viral integration: Exploitation of humans by viruses}

For a long time, major mental disorders like autism and schizophrenia have been suspected of having a genetic component, but uncovering it has met with limited success. Part of the reason could be that carrying a particular gene does not entail that it must be active; depending on various environmental circumstances, which in mice include maternal stress, genes in offspring can be turned on or off (for a review, see Seckl \& Holmes, 2007). Recent work suggests that viruses, too, even common ones like cytomegalovirus, can mess with our genes (Børglum et al., 2014).

Cytomegalovirus is a herpes virus that infects the majority of the world's population. In the United States, it has been estimated to be present in nearly $60 \%$ of people over 6 years of age and in more than $90 \%$ of those over 80 (in the period 1988-1994: Staras et al., 2006; see also Simanek et al., 2011). The infection is usually benign (but see Simanek et al., 2011). However, Børglum and colleagues (2014) found, in a very large sample, that this was not the case for the $15 \%$ of their subjects who carried a particular variant (by itself also benign) of a gene involved in the stabilization of neuronal connections and in synaptic plasticity, essential to learning and memory (for a review, see Arikkath \& Reichardt, 2008). In the carriers of this gene variant, maternal cytomegalovirus infection increased fivefold the probability of developing schizophrenia.

The extent to which viruses can become assimilated with us is vividly illustrated by endogenous viruses, the best known among which are retroviruses. Like HIV, retroviruses use RNA to produce DNA, the converse (hence, "retro") of the usual pattern. This viral DNA is then inserted into the host's DNA; whenever it replicates its own DNA, an infected host's cell inadvertently reproduces the retrovirus-often with mutations that render it difficult to target with antiviral drugs (Svarovskaia, Cheslock, Zhang, Hu, \& Pathak, 2003). The new retrovirus leaves the cell and goes on to infect other ones.

Unlike HIV, at one point in their history some retroviruses infected animals' germline cells, those that eventually develop into sperm or eggs. Accordingly, these retroviruses replicate not only every time the cells they have infected reproduce their own DNA but also every time the carrier of the cells reproduces with a mate. It follows that the DNA of these now endogenous retroviruses is present not just in a particular host but also in each and every cell of the host's descendants. The DNA of human endogenous retroviruses occupies at least $8 \%$ of our genome; genetic material of so-called jumping genes, which resemble retroviruses and may also have a viral origin, comprises another $37 \%$.

The viral DNA embedded in our own DNA was already present in our human and even prehuman ancestors; it can be from hundreds of thousands to tens of millions of years old (Lander et al., 2001; for a review, see Magiorkinis, Belshaw, \& Katzourakis, 2013). Because it is reproduced whenever our DNA is, this viral DNA is thought to have evolved so as to lose its harmfulness (Haig, 2012). In fact, it is now usually either inactive or silenced by the host; two genes of viral origin even promote our own replication by playing an essential role in the formation of the human feto-maternal interface, the placenta. Viral genes like these may actually have been central in the emergence of placental mammals from egg-laying animals (for a review, see Lavialle et al., 2013; Mi et al., 2000). 
It might be argued that endogenous viruses are so intimately integrated with us that they should be considered part of our organism rather than superorganism. Crucially, though, the fitness of viral elements-however deeply integrated into our genome these can be-need not coincide with ours. Inactive viral elements, for example, are useless to us and, because our cells inadvertently reproduce them, merely exploit our resources. Worse, harmful viral elements that are normally inactive can be reactivated by various pathogens (Frank, Jones-Brando, Leib-Mosch, Yolken, \& Seifarth, 2006). The influenza virus (Nellåker et al., 2006), for example, is capable of reactivating normally inactive endogenous retroviral elements that (a) can cause neuroinflammation, along with white matter and myelin degeneration, and (b) have been implicated in bipolar disorder and schizophrenia (Perron et al., 2012; for a related review, see Leboyer, Tamouza, Charron, Faucard, \& Perron, 2013), although both independent replication and a clarification of the mechanism involved in the reactivation are still lacking.

\section{Viral integration: Exploitation of viruses by humans}

In recent history, humans have begun to parasitize their parasites. Some viruses are modified in the laboratory and then used to infect people to treat various genetic conditions, including several that affect the brain (for reviews, see Gray, 2013; Lentz, Gray, \& Samulski, 2012; Simonato et al., 2013). In one study (LeWitt et al., 2011), for example, 16 patients with Parkinson's disease had a modified virus, containing genes that modulate the neurotransmitter GABA, injected into their brain. Relative to a control group of 21 patients who had received a sham injection, the motor ability of the experimental group improved by about $10 \%$-a modest but promising first step in the development of a radically new treatment of Parkinson's disease. Modified retroviruses have been used as well. In six patients with Alzheimer's, for example, degeneration was reduced (on one physiological and two behavioral measures) with the help of a modified leukemia retrovirus (Tuszynski et al., 2005). The modified retrovirus contained genes that induced infected cells to produce nerve growth factor; cells infected in vitro were then implanted into the patient's brain, in a specific area that promotes cortical plasticity and memory. It would in principle seem possible to purposely infect germline cells, too (which might herald a revival of eugenics); however, no attempts to modify endogenous, as opposed to exogenous, retroviruses appear to have been made yet.

\section{Foreign Human Cells}

Evidence is mounting that our brain (and behavior) can also be permanently modified by the invasion of selfish entities that are not microorganisms or viruses but the cells of another person. The likeliest time of infiltration would have been when we were fetuses, with either our mother or our twin as the intruders. As we will see, some of these foreign cells go on to multiply and form large patches of the host's body and brain; hence, their integration is exquisite-they literally become the cells of their hosts. Yet of course they can still be distinguished from the host's "own" cells, because they carry a different genome-and the selfish interests they pursue coincide with those of the host's "own" cells only for those genes that are shared. (The use of quotation marks around "own" expresses the notable technicality that, on occasion, it might prove impossible to say who is the host and who is the guest.)

\section{Invasion of the fetus by the mother}

During pregnancy, a mother's immune system can regard the fetus as an intruder and mount an immune response to it much as it would to a virus or some other kind of parasite. In particular, maternal antibodies can attack proteins in the fetal brain and disturb its growth, causing neurodevelopmental disorders. Maternal antibodies reactive to fetal brain proteins are found in about $12 \%$ of women who have a child with autism but not in mothers of typically developing children (Braunschweig et al., 2008). Indeed, if blood serum (which contains antibodies) from mothers of children with conditions such as autism (Dalton et al., 2003) or dyslexia (Vincent et al., 2002) is injected into pregnant mice, the mouse offspring shows altered brain growth and behavioral deficits, whereas this is not the case if the serum comes from mothers of healthy children (for similar results with rhesus monkeys, see Martin et al., 2008; and Bauman et al., 2013). 
Recognizing the fetus as foreign is especially likely when it is male. If the fetal cells that enter the mother's circulation during pregnancy or childbirth belong to a boy, they may carry male-specific substances that the mother's immune system will identify as foreign, given that she is female (Wolf, Schempp, \& Scherer, 1992). Some of these substances are proteins linked to the $Y$ chromosome (known collectively as H-Y antigen; an antigen is any substance that, being labeled as foreign by the immune system, stimulates the production of antibodies). Women who have been exposed to male tissues, by either receiving transplants from male donors or giving birth to sons, have a particularly strong immune reaction to these proteins for as long as 20 or more years after exposure (for a review, see Bogaert \& Skorska, 2011).

At least four Y-linked proteins in the fetal brain might have a key role in its sexual differentiation (Bogaert \& Skorska, 2011). If maternal antibodies bind to such molecules, inactivating them, the male brain may develop as though these molecules were absent (much as in the female fetus), redirecting sexual orientation from typically male to typically female. Importantly, the number and effectiveness of maternal antibodies, and thus the likelihood that-if this hypothesis holdsthe fetus is affected, increase as male-specific substances are encountered again and again in successive pregnancies. It has been argued that this mechanism may be one route to homosexual development in men (for reviews of indirect but abundant evidence, see Blanchard, 2004; Bogaert \& Skorska, 2011). Consistent with this pregnancy-order effect, the more sons a woman has given birth to (or even miscarried), the higher the probability that her next son will be homosexual (e.g., Blanchard, 2004). Daughters and adopted children do not influence these odds. Remarkably, a man is twice as likely to be homosexual if he has, on average, 2.5 older brothers than if he has none and three times as likely if he has four older brothers.

It might seem odd that a mother's immune targeting of her son's H-Y antigen could demasculinize his sexual orientation without demasculinizing his genitalia or other sex-dimorphic physical features, such as his weight or height. This selectivity is, in fact, not impossible (Blanchard \& Klassen, 1997), as suggested by evidence that, in mice, testes can develop when H-Y antigen is totally absent (McLaren, Simpson, Tomonari, Chandler, \& Hogg, 1984). Still, homosexual males with two or more older brothers do tend to be lighter at birth (Blanchard \& Ellis, 2001) and shorter as adults (Bogaert, 2003) than heterosexual males and homosexual males with one or no older brothers.

A mother's antimale antibodies may also affect the developing male brain in other ways. For example, boys are more likely than girls to experience neurodevelopmental and psychiatric disorders (Gualtieri \& Hicks, 1985), and boys with intellectual disabilities are more likely to have older brothers but not more likely to have older sisters than boys who are typically developing (Flannery \& Liederman, 1994) - which is particularly difficult to explain with alternative theories.

Feto-maternal trafficking occurs both ways. During pregnancy, a woman acquires cells from her fetus, some of which are stem or progenitor cells (for a review, see Bianchi, 2007). Such cells can become integrated into the mother's lungs, liver, heart, skin, and even her brain; they particularly tend to accumulate and multiply in organs that are injured or diseased. Any behavioral consequences of the presence of fetal tissue in the brains of mothers remain to be investigated, but this occurrence is impressively frequent: Chan et al. (2012) found that $63 \%$ of the 59 women they tested harbored male cells in their brains (cells coming presumably from fetuses; but see next section).

\section{Invasion of the fetus by another fetus}

The presence in one person of cells from another person is called chimerism (from Chimera, the mythological monster composed of parts of different animals). Chimerism can result not only from postbirth events, such as having carried a fetus or received an organ transplant or blood transfusion, but also by being, often unknowingly, a twin. One well-documented case regards a woman who, entirely by accident, was found not to be the biological mother of two of her three sons (Yu et al., 2002). It turned out that she had originated from two genomes, presumably belonging to dizygotic (nonidentical) twin sisters who had fused in the womb. One genome had 
given rise to the whole of her blood and some of her eggs, the other to the remaining eggs.

Such cases may be not as rare as one would think. When specifically looked for, blood group chimerism has been found, respectively, in $8 \%$ and $21 \%$ of dizygotic twins and triplets (van Dijk, Boomsma, \& de Man, 1996). These numbers must represent a small fraction of all cases, given that (a) chimerism can be present without showing up as different blood groups, and (b) twin conceptions result in twin births only sporadically; sole survivors (where the co-twin has initially progressed and then vanished or has failed to develop altogether) are estimated to be at least as frequent as one live birth in eight (Boklage, 1995). (Extreme "fetus-in-fetu" cases, in which a whole parasitic twin was found in the body of its live co-twin, have also been reported; e.g., Gangopadhyay et al., 2010.)

Chimerism might help turn around what we have always believed about twinning. Boklage (e.g., 2009), for example, has persuasively argued that (a) dizygotic twins originate from a single mass of cells, and as such-barring absolute perfection in the halving process-they will in some measure be chimeric; (b) more often than not, this mass develops into one individual rather than two, and that individual will inevitably be chimeric. These ideas are controversial, because it is commonly assumed that dizygotic twins come from fertilization by separate sperms of separate eggs (due to "double ovulation") and thus have never been together in a single mass. However, not only does the hypothesis of double ovulation remain unsupported, but several lines of evidence are inconsistent with it (for review and discussion, see Boklage, 2006, 2009).

Arguably in dizygotes, and certainly in monozygotes, twin embryogenesis implies building two bodies from a single mass of cells and thus doubling the three sets of body axes-including the left-right one, crucial to the establishment of asymmetrical structures around the body's midline, from the position of the heart to the difference between the left and right hemispheres of the brain. The early coexistence of two such plans might well interfere with the determination of normal functional asymmetries (Boklage, 2006). Indeed, midline fusion anomalies (such as cleft lip or spina bifida) and nonrighthandedness are observed more frequently among twins, both monozygotic and dizygotic, than among nontwins (Boklage, 2006; Derom, Thiery, Vlietinck, Loos, \& Derom, 1996). Other behavioral consequences of twin embryogenesis might include psychiatric conditions such as bipolar disorder and schizophrenia (Boklage, 1977b; Klar, 2004). As a matter of fact, schizophrenia has been related to the mechanisms that drive asymmetric brain development (Crow, 1990) and is associated with nonrighthandedness and reduced hemispheric lateralization (Boklage, 1977b; DeLisi et al., 1997).

\section{Imprinted Genes}

All of us, without exception, carry genes originally designed to produce viruses; those of us who are chimeric also carry genes designed to produce separate human beings. In both cases, this foreign genetic material has been assimilated to the point of becoming effectively our own, but its identity can still be recognized as separate. The rest of our genes we commonly regard as unquestionably ours, and their integration is such that it might be hard to see them as selfish participants in a superorganism - to envisage their interests as distinct from our "own." The particular genes reviewed here, imprinted genes, will make this idea easier to contemplate.

Of all genes, except those on sex chromosomes in males, we normally inherit two copies, one from each parent. As a rule, both are active (Gimelbrant, Hutchinson, Thompson, \& Chess, 2007). Of some genes, however, at one or more stages of development, and in some cases in one sex and not the other, only the maternally or paternally inherited copy is active while the other is silenced ("imprinted"; Gregg, Zhang, Butler, Haig, \& Dulac, 2010; Gregg, Zhang, Weissbourd, et al., 2010). According to a leading theory, discussed below, imprinting benefits our parents' fitness (for a review, see Crespi \& Badcock, 2008) but not necessarily our own; in fact, imprinted genes are among the genes most frequently implicated in physical and mental disorders (J. T. Lee \& Bartolomei, 2013).

\section{Mechanisms of imprinted genes' integration in the human superorganism}

Although it is embedded within our own, the DNA of endogenous retroviruses is, as mentioned, 
often silenced. Some imprinted genes are suspected to be of viral origin or under the control of genes that are (Keverne, 2013); indeed, imprinting might have evolved, in part, from defensive silencing of viral DNA (Haig, 2012; Keverne, 2013). Still, of the two copies of each imprinted gene, only one is silenced. Which copy is silenced depends on the parent from which it was inherited; that is, one parent turns its copy on while the other turns its off. According to the conflict or kinship theory - the currently dominant theory on this topic-imprinted genes perform functions that benefit one parent more than the other, and a tug-ofwar ensues about their activation. The root of the conflict lies in the fact that whereas-besides endogenous virusestwo parties benefit from human procreation (mothers and fathers), only one of them is sure to pay its costs: mothers (for reviews, see Haig, 2002, 2011; Wilkins \& Haig, 2003).

The fetus extracts maternal resources via the placenta, which develops in the mother's womb but contains, like the fetus, both maternal and paternal genes. The growth of fetus and placenta is important to both parents, but because each parent can reproduce again with a different mate, conserving maternal resources for future reproduction is more important to mothers than to fathers (Haig, 1993). Consistently, the paternally inherited genes in the fetus and placenta tend to stimulate growth - and thus the extraction of resources from the mother-whereas the maternally inherited ones do not or even actively limit growth. In other words, copies of growthpromoting imprinted genes tend to be active when inherited from the father and silenced when inherited from the mother, and copies of growth-limiting imprinted genes tend to be silenced when inherited from the father and active when inherited from the mother (for reviews, see Fowden, Coan, Angiolini, Burton, \& Constancia, 2011; Kopsida, Mikaelsson, \& Davies, 2011; J. T. Lee \& Bartolomei, 2013; Swaney, 2011; cf. Keverne \& Curley, 2008). In fact, it is to defend herself from an overly invasive placenta that the mother temporarily builds up-before possible conception - a protective uterine lining, which in the absence of conception is shed during menstruation (Emera, Romero, \& Wagner, 2012). It has been suggested (Haig, 1993) that excessive paternally induced resource extraction could be the root cause of common, and until the nineteenth century not infrequently fatal (Todman, 2007), complications during pregnancy and delivery.

\section{Effects of imprinted genes on behavior}

A still somewhat speculative extension of the conflict theory of imprinting, the diametric model, focuses specifically on the mental development of the fetus (Crespi \& Badcock, 2008; see also Badcock \& Crespi, 2008; Del Giudice, Angeleri, Brizio, \& Elena, 2010; Del Giudice, Klimczuk, Traficonte, \& Maestripieri, 2014). As mentioned, paternally induced imprinting tends to promote the transfer of resources from mother to fetus, whereas maternally induced imprinting tends to limit it. Badcock and Crespi (2008) hypothesized that a moderate paternal bias would result not only in a heavier baby but also in a more demanding child, in which fewer resources have been spent on the development of those prosocial behaviors that would benefit the primary caregiver, the mother. Conversely, a moderate maternal bias would result not only in a lighter baby but also in a less demanding and more easygoing child.

As either of the two diametrically opposite biases increases, the risk of pathological exaggerations of these developmental patterns would increase, too. The most controversial claim of the theory is that an extreme paternal bias would lead to autism-spectrum disorders (such as attention-deficit/hyperactivity disorder, obsessive-compulsive disorder, and especially autism) and an extreme maternal bias to psychosis-spectrum disorders (such as bipolar disorder, major depression, and especially schizophrenia). Autism is characterized by restricted interests, repetitive behaviors, and reduced social and communication skills and interests; schizophrenia by positive or psychotic symptoms (delusions, hallucinations, and paranoia), negative symptoms (reduced emotional expression, lack of motivation, and social withdrawal), and disorganization (incoherent speech and perseveration).

Autism and psychosis are heterogeneous mental conditions, and someone may very well develop both (Badcock, 2009). This is not inconsistent with the diametric model; the two disorders should be expected to be diametric opposites only at the level of single genes. Yet, consistent with the theory, a recent large-scale, genomewide study found that although depression and schizophrenia share particular genetic variants with one another, they share respectively few 
and none with autism (S. H. Lee et al., 2013).

Support for the diametric model comes primarily from pairs of genetic disorders that involve the same genes but are associated with opposite physical and psychological characteristics. The most convincing evidence for the theory concerns irregularities on chromosome 11, on which only the paternally inherited copy of the growthpromoting IGF2 gene and the maternally inherited copy of the growth-limiting H19 gene are active prenatally (Gregg, Zhang, Weissbourd, et al., 2010). If the former is up-regulated or the latter down-regulated, the baby risks being born with Beckwith-Wiedemann syndrome; if the converse occurs, with Silver-Russell syndrome (for an independent review, see Azzi, Abi Habib, \& Netchine, 2014). In Beckwith-Wiedemann syndrome, typical symptoms include fetal and placental overgrowth, pointing to an increased burden on the mother; in Silver-Russell syndrome, typical symptoms include pre- or postnatal undergrowth (dwarfism), pointing to a decreased burden on the mother. For Silver-Russell syndrome, which is rare, there are insufficient data to test the prediction of a higher risk of psychosis-spectrum disorders. Consistent with the diametric model, however, Beckwith-Wiedemann syndrome does increase the risk of autism-spectrum disorders (Kent, Bowdin, Kirby, Cooper, \& Maher, 2008). In addition, the paternally inherited IGF2 gene has been associated with superior semantic memory (for a review, see Alberini \& Chen, 2012), and savant mnemonic skills are strongly linked to autism (for a review, see Hughes, 2010).

Another well-studied pair of syndromes is related to imprinted genes on chromosome 15 (for reviews, see Cassidy, Schwartz, Miller, \& Driscoll, 2012; Ishida \& Moore, 2013; Kopsida et al., 2011; Williams, Driscoll, \& Dagli, 2010). Angelman syndrome (paternal bias) is characterized by a strikingly happy demeanor but also by prolonged suckling and thus delayed weaning, hyperactivity, sleeplessness, and poor verbal skills-symptoms that suggest an increased burden on the mother. Prader- Willi syndrome (maternal bias), on the contrary, is characterized by low birth weight, poor suckling, inactivity, sleepiness, and a high pain threshold and thus few complaints about pain-symptoms that suggest a decreased burden on the mother. Consistent with the diametric model, Angelman syndrome has been associated with autism-spectrum disorders (Mertz et al., 2014); the most extreme version of Prader-Willi syndrome-involving two maternally inherited copies of chromosome 15 and no paternally inherited one-has been associated with psychosis-spectrum disorders (Webb et al., 2008).

On average, consistent with the diametric model, any genetic changes that favor the growth of nerve dendrites are associated with autism, whereas those that inhibit it are associated with schizophrenia (for evidence and review, see Gilman et al., 2012). Also, people with a birth weight or height slightly above average are more susceptible to autism- than to schizophrenia-spectrum disorders, and people with a birth weight or height slightly below average are more susceptible to schizophreniathan to autism-spectrum disorders (Byars, Stearns, \& Boomsma, 2014).

\section{Practical Implications and Research Directions}

Our primary goal here was to put forth a different perspective on psychological science than the one commonly shared by those working in the field. However, the findings and theories we have presented also yield concrete suggestions for improving the development and application of psychological tests and therapies, for reducing noise and confounds in psychological research, and for further investigation. We offer a few examples that span different sections of our article.

1. Psychotherapy might be less successful when mental problems are due to ongoing infections. One should bear this in mind when deciding on a therapy or judging its effectiveness; given that Toxoplasma infection, for instance, is quite common, studying infected subjects separately from uninfected ones may dispose of an important source of noise. This may not require ad hoc medical examinations; in Italy, for example, all pregnant women are tested for Toxoplasma infection as a part of standard prenatal care. Psychological scientists could thus compare the efficacy of psychotherapies in infected and uninfected people straight away, at least in this group. Likewise, when investigating the causes of homosexuality, dyslexia, or autism, one may consider birth order or the presence of similarly affected siblings as a possible proxy for the prenatal action of maternal antibodies, even if one is not interested in these antibodies and merely wants 
to exclude them as a confound.

2. Prenatal events matter. Clinical psychologists and psychiatrists normally pay close attention to the environment in which patients live or grew up, but even what happened before the patient's birth can have permanent effects. For example (Yehuda et al., 2005), pregnant women who developed posttraumatic stress disorder following the attack on New York's World Trade Center on September 11, 2001, gave birth to children with lower cortisol levels (itself a proxy for posttraumatic stress disorder). Maternal Toxoplasma or cytomegalovirus infections are far more common than such external disasters, and they can affect the future mental health of unborn offspring, too. Failing to take such effects into account may hamper our complete understanding of even seemingly unrelated data. For example, some cases of concordance for schizophrenia in twins might mistakenly be interpreted as the result of shared genes when they are, in fact, due to shared exposure to maternal infection during gestation.

3. Twin studies might provide equivocal data. To determine how much some behavior, ability, or mental disease is heritable, psychological scientists often rely on studies in which monozygotic and dizygotic twins are compared. It is assumed that monozygotic twins are genetically identical whereas dizygotic twins are as genetically similar as any pair of siblings. If, however, chimerism between cotwins is as frequent as we have reported, this latter assumption might be invalid. Incidentally, twinning is the result of an anomaly in embryonic symmetry development, hence in the establishment of laterality, and in this regard twins are not comparable to nontwin siblings either. Special caution is thus warranted (Boklage, 1977a) when twin data are used to draw conclusions about those aspects of mental development that are associated with laterality, such as schizophrenia.

4. Microbiota modification might complement psychotherapy. Some cases of aberrant behavior associated with imbalances in the gut microbiota may require a dietary treatment rather than, or in addition to, psychotherapy. In a subset of children with autism, for example, behavioral symptoms get better both during specific diets (for a recent review, see Whiteley et al., 2013), which might or might not point to a role of the microbiota, and during antibiotic treatment (Ramirez, Barnhill, Gutierrez, Schutte, \& Hewitson, 2013; Sandler et al., 2000), which certainly does. Fecal transplants are sometimes performed on humans to treat intestinal disease; given that they have been shown to alter behavior in mice, it would be of both theoretical and clinical interest to investigate whether similar but still anecdotal evidence in humans can be corroborated. Considering the unquestionable success of probiotics in trials with rodents, further clinical study of the psychological benefits of bifidobacteria and lactobacilli in humans ought to be encouraged as well-preferably with funding that does not come, as is currently the case, from companies that produce or market yogurt. A full understanding of human behavior may require considering gut microbes' evolutionary interests in less conventional ways, too. To cite just one of them, circumstantial evidence is accumulating that people's craving for certain foods might be driven by the bacteria that thrive on such foods, and a number of testable predictions have been offered (Alcock, Maley, \& Aktipis, 2014). One proposal, for example, rests on the expectation that an increase in microbiota diversity will tend to redirect the bacteria's resources from host manipulation to competition with rivals; if so, food cravings should diminish with the intake of probiotics that increase this diversity but not of probiotics that leave it unaffected. These kinds of studies would certainly benefit from the collaboration of experts in psychological assessment and may have important implications for research on eating disorders and for public health policies.

5. Even methodological research may profit from the findings we have presented here. For example, the diametric model points to weaknesses in popular questionnaires measuring autistic or psychotic tendencies: both types of questionnaires assess social withdrawal, but their relevant items do not all distinguish whether this is due, say, to a lack of interest in people (associated with autistic tendencies) or a paranoid concern about them (associated with psychotic tendencies). This oversight may thus spuriously suggest an overlap between autistic and psychotic tendencies that may be no more than an overlap between the questionnaires that measure them (Del Giudice et al., 2010; Dinsdale, Hurd, Wakabayashi, Elliot, \& Crespi, 2013). 


\section{Conclusion}

Although our immune system has been shaped over millions of years to recognize and destroy nonself cells, all the entities described here share a demonstrable capability to circumvent, defeat, or hijack our defenses. For better and for worse, these entities will be assimilated; (immune) resistance is futile. The degree to which they become assimilated, hence the stability of their contribution to the human superorganism, varies greatly (Table 1) and is tightly linked to their own survival strategies. Some brain microbes, for example, evade our immune response by hiding within protective cysts; several strains of gut microbes have made themselves so indispensable that we have actually evolved ways to foster their invasion; some viruses trick our reproductive system into replicating their own genetic material inside ours and our offspring's; our dizygotic twin's cells enter us before our immune system has learned to distinguish self from nonself; imprinted genes promote their interests while working from within.

Notwithstanding their differences, all these entities share a long-term location (the human body), an ultimate purpose (dispersing progeny to new bodies), a modus operandi (interacting with our bodily systems, including our nervous one), and psychology-relevant mementos-their effects on our brain and behavior. Whereas our cohabitation with one or another of them may not pose a strong challenge to the commonly shared assumption that humans are unitary individuals, the presence of a large number and wide variety of such entities-and the power they have on usrenders this assumption untenable. We are not organisms but superorganisms, and understanding our behavior ultimately requires an understanding of the network of selfish entities that inhabit our body and actively interact with it. It is time to change the very concept we have of ourselves and to realize that one human individual is neither just human nor just one individual.

The explosion of information available to scientists has made specialization more necessary than ever, but this comes at the risk of losing sight of relevant research in other disciplines.

Psychologists have taken countermeasures by engaging in studies that bridge related disciplines, such as neuroscience, linguistics, artificial intelligence, philosophy, and anthropology. Our point here, however, is that disciplines that ostensibly have little or nothing to do with either psychology or psychiatry-like parasitology, virology, gastroenterology, immunology, and embriology - can and do produce research that is extraordinarily relevant to both. We thus call for more collaboration among scientists who currently appear to live on different planets. We also call for greater exchange of information, or straight collaboration, among healthcare professionals. It might even be desirable if some of us become specialists not in any particular profession or research area but in integrating information from different disciplines. We have shown that each of us is a superorganism; but to function at its best, our scientific and professional community should perhaps become a bit more like one, too.

\section{Acknowledgments}

We thank Caterina Trainito for helpful comments on an earlier version and Nino Trainito for technical assistance in preparing Figure 1.

Peter Kramer and Paola Bressan contributed equally to this work.

\section{Declaration of Conflicting Interests}

The authors declared that they had no conflicts of interest with respect to their authorship or the publication of this article.

Peter Kramer, Dipartimento di Psicologia Generale, Università di Padova, Via Venezia 8, 35131 Padova, Italy E-mail: peter.kramer@unipd.it

Paola Bressan, Dipartimento di Psicologia Generale, Università di Padova, Via Venezia 8, 35131 Padova, Italy E-mail: paola.bressan@unipd.it

\section{References}

Alberini, C. M., \& Chen, D. Y. (2012). Memory enhancement: Consolidation, reconsolidation and insulin-like growth factor 2. Trends in Neurosciences, 35, 274-283. doi:10.1016/j .tins.2011.12.007 
Alcock, J., Maley, C. C., \& Aktipis, C. A. (2014). Is eating behavior manipulated by the gastrointestinal microbiota? Evolutionary pressures and potential mechanisms. BioEssays, 36, 940-949. doi:10.1002/bies.201400071

Arikkath, J., \& Reichardt, L. F. (2008). Cadherins and catenins at synapses: Roles in synaptogenesis and synaptic plasticity. Trends in Neurosciences, 31, 487-494.

Aspinall, T. V., Marlee, D., Hyde, J. E., \& Sims, P. F. (2002). Prevalence of Toxoplasma gondii in commercial meat products as monitored by polymerase chain reaction- Food for thought? International Journal for Parasitology, 32, 1193-1199.

Azzi, S., Abi Habib, W., \& Netchine, I. (2014). Beckwith- Wiedemann and Russell-Silver syndromes: From new molecular insights to the comprehension of imprinting regulation. Current Opinion in Endocrinology, Diabetes and Obesity, 21, 30-38. doi:10.1097/MED.0000000000000037

Badcock, C. (2009). The imprinted brain: How genes set the balance between autism and psychosis. London, England: Jessica Kingsley Publishers.

Badcock, C., \& Crespi, B. (2008, August 28). Battle of the sexes may set the brain. Nature, 454, 1054-1055. doi:10.1038/4541054a

Bauman, M. D., Iosif, A. M., Ashwood, P., Braunschweig, D., Lee, A., Schumann, C. M., ... Amaral, D. G. (2013). Maternal antibodies from mothers of children with autism alter brain growth and social behavior development in the rhesus monkey. Translational Psychiatry, 3, e278. doi:10.1038/tp.2013.47

Bercik, P., Denou, E., Collins, J., Jackson, W., Lu, J., Jury, J., . . . Collins, S. M. (2011). The intestinal microbiota affect central levels of brain-derived neurotropic factor and behavior in mice. Gastroenterology, 141, 599-609, 609.e1-3. doi:10.1053/j.gastro.2011.04.052

Bercik, P., Verdu, E. F., Foster, J. A., Macri, J., Potter, M., Huang, X., ... Collins, S. M. (2010). Chronic gastrointestinal inflammation induces anxiety-like behavior and alters central nervous system biochemistry in mice. Gastroenterology, 139, 2102-2112.e1. doi:10.1053/j.gastro.2010.06.063

Bested, A. C., Logan, A. C., \& Selhub, E. M. (2013). Intestinal microbiota, probiotics and mental health: From Metchnikoff to modern advances: Part II-Contemporary contextual research. Gut Pathogens, 5(1), Article 3. doi:10.1186/1757- 4749-5-3

Bewernick, B. H., Hurlemann, R., Matusch, A., Kayser, S., Grubert, C., Hadrysiewicz, B., ... Schlaepfer, T. E. (2010). Nucleus accumbens deep brain stimulation decreases ratings of depression and anxiety in treatment-resistant depression. Biological Psychiatry, 67, 110-116. doi:10.1016/ j.biopsych.2009.09.013

Bianchi, D. W. (2007). Fetomaternal cell trafficking: A story that begins with prenatal diagnosis and may end with stem cell therapy. Journal of Pediatric Surgery, 42, 12-18. doi:10.1016/j.jpedsurg.2006.09.047

Blanchard, R. (2004). Quantitative and theoretical analyses of the relation between older brothers and homosexuality in men. Journal of Theoretical Biology, 230, 173-187. doi:10.1016/j.jtbi.2004.04.021

Blanchard, R., \& Ellis, L. (2001). Birth weight, sexual orientation and the sex of preceding siblings. Journal of Biosocial Science, 33, 451-467.

Blanchard, R., \& Klassen, P. (1997). H-Y antigen and homosexuality in men. Journal of Theoretical Biology, 185, 373-378. doi:10.1006/jtbi.1996.0315

Bogaert, A. F. (2003). The interaction of fraternal birth order and body size in male sexual orientation. Behavioral Neuroscience, 117, 381-384. doi:10.1037/0735-7044.117.2.381

Bogaert, A. F., \& Skorska, M. (2011). Sexual orientation, fraternal birth order, and the maternal immune hypothesis: A review. Frontiers in Neuroendocrinology, 32, 247-254. doi:10.1016/j.yfrne.2011.02.004

Boklage, C. E. (1977a). Embryonic determination of brain programming asymmetry-Caution concerning the use of data on twins in genetic inferences about mental development. Annals of the New York Academy of Sciences, 299, 306-308. doi:10.1111/j.1749-6632.1977.tb4191

Boklage, C. E. (1977b). Schizophrenia, brain asymmetry development, and twinning: Cellular relationship with etiological and possibly prognostic implications. Biological Psychiatry, 12(1), 19-35.

Boklage, C. E. (1995). The frequency and survival probability of natural twin conceptions. In L. Keith, E. Papiernik, D. Keith, \& B. Luke (Eds.), Multiple pregnancy: Epidemiology, gestation and perinatal outcome (pp. 41-50). New York, NY: Parthenon Publishers.

Boklage, C. E. (2006). Embryogenesis of chimeras, twins and anterior midline asymmetries. Human Reproduction, 21, 579-591. doi:10.1093/humrep/dei370

Boklage, C. E. (2009). Traces of embryogenesis are the same in monozygotic and dizygotic twins: Not compatible with double ovulation. Human Reproduction, 24, 1255-1266. doi:10.1093/humrep/dep030

Børglum, A. D., Demontis, D., Grove, J., Pallesen, J., Hollegaard, M. V., Pedersen, C. B., . . Mors, O. (2014). Genome-wide study of association and interaction with maternal cytomegalovirus infection suggests new schizophrenia loci. Molecular Psychiatry, 19, 325-333. doi:10.1038/mp.2013.2

Borody, T. J., Paramsothy, S., \& Agrawal, G. (2013). Fecal microbiota transplantation: Indications, methods, evidence, and future directions. Current Gastroenterology Reports, 15(8), Article 337. doi:10.1007/s11894-013-0337-1

Braunschweig, D., Ashwood, P., Krakowiak, P., Hertz-Picciotto, I., Hansen, R., Croen, L. A., ... Van de Water, J. (2008). Autism: Maternally derived antibodies specific for fetal brain proteins. NeuroToxicology, 29, 226-231. doi:10.1016/j .neuro.2007.10.010

Bravo, J. A., Forsythe, P., Chew, M. V., Escaravage, E., Savignac, H. M., Dinan, T. G., ... Cryan, J. F. (2011). Ingestion of lactobacillus strain regulates emotional behavior and central GABA receptor expression in a mouse via the vagus nerve. Proceedings of the National Academy of Sciences, USA, 108, 16050-16055. 
doi:10.1073/pnas.1102999108

Byars, S. G., Stearns, S. C., \& Boomsma, J. J. (2014). Opposite risk patterns for autism and schizophrenia are associated with normal variation in birth size: Phenotypic support for hypothesized diametric genedosage effects. Proceedings of the Royal Society B: Biological Sciences, 281. doi:10.1098/ rspb.2014.0604.

Cassidy, S. B., Schwartz, S., Miller, J. L., \& Driscoll, D. J. (2012). Prader-Willi syndrome. Genetics in Medicine, $14,10-26$.

Chan, W. F., Gurnot, C., Montine, T. J., Sonnen, J. A., Guthrie, K. A., \& Nelson, J. L. (2012). Male microchimerism in the human female brain. PLOS ONE, 7(9), e45592. doi:10.1371/journal.pone.0045592

Collinger, J. L., Wodlinger, B., Downey, J. E., Wang, W., Tyler- Kabara, E. C., Weber, D. J., ... Schwartz, A. B. (2013). High-performance neuroprosthetic control by an individual with tetraplegia. The Lancet, 381, 557-564. doi:10.1016/ S0140-6736(12)61816-9

Crespi, B., \& Badcock, C. (2008). Psychosis and autism as diametrical disorders of the social brain. Behavioral \& Brain Sciences, 31, 241-261; discussion 261-320. doi:10.1017/ S0140525X08004214

Crow, T. J. (1990). Temporal lobe asymmetries as the key to the etiology of schizophrenia. Schizophrenia Bulletin, 16, 433-443.

Cryan, J. F., \& Dinan, T. G. (2012). Mind-altering microorganisms: The impact of the gut microbiota on brain and behaviour. Nature Reviews Neuroscience, 13, 701-712. doi:10.1038/nrn3346

Dalton, P., Deacon, R., Blamire, A., Pike, M., McKinlay, I., Stein, J., . . Vincent, A. (2003). Maternal neuronal antibodies associated with autism and a language disorder. Annals of Neurology, 53, 533-537. doi:10.1002/ana.10557

Dantzer, R., O'Connor, J. C., Freund, G. G., Johnson, R. W., \& Kelley, K. W. (2008). From inflammation to sickness and depression: When the immune system subjugates the brain. Nature Reviews Neuroscience, 9, 46-56. doi:10.1038/ nrn2297

Del Giudice, M., Angeleri, R., Brizio, A., \& Elena, M. R. (2010). The evolution of autistic-like and schizotypal traits: A sexual selection hypothesis. Frontiers in Psychology, 1, Article 41. doi:10.3389/fpsyg.2010.00041

Del Giudice, M., Klimczuk, A. C. E., Traficonte, D. M., \& Maestripieri, D. (2014). Autistic-like and schizotypal traits in a life history perspective: Diametrical associations with impulsivity, sensation seeking, and sociosexual behavior. Evolution \& Human Behavior, 35, 415-424. doi:10.1016/j. evolhumbehav.2014.05.007

DeLisi, L. E., Sakuma, M., Kushner, M., Finer, D. L., Hoff, A. L., \& Crow, T. J. (1997). Anomalous cerebral asymmetry and language processing in schizophrenia. Schizophrenia Bulletin, 23, 255-271.

Derom, C., Thiery, E., Vlietinck, R., Loos, R., \& Derom, R. (1996). Handedness in twins according to zygosity and chorion type: A preliminary report. Behavior Genetics, 26, 407-408.

Desbonnet, L., Garrett, L., Clarke, G., Kiely, B., Cryan, J. F., \& Dinan, T. G. (2010). Effects of the probiotic bifidobacterium infantis in the maternal separation model of depression. Neuroscience, 170, 1179-1188. doi:10.1016/j.neuroscience. 2010.08.005

Diaz Heijtz, R., Wang, S., Anuar, F., Qian, Y., Björkholm, B., Samuelsson, A., . . Pettersson, S. (2011). Normal gut microbiota modulates brain development and behavior. Proceedings of the National Academy of Sciences, USA, 108, 3047-3052. doi:10.1073/pnas.1010529108

Dinan, T. G., Stanton, C., \& Cryan, J. F. (2013). Psychobiotics: A novel class of psychotropic. Biological Psychiatry, 74, 720-726. doi:10.1016/j.biopsych.2013.05.001

Dinsdale, N. L., Hurd, P. L., Wakabayashi, A., Elliot, M., \& Crespi, B. J. (2013). How are autism and schizotypy related? Evidence from a non-clinical population. PLoS ONE, 8(5), e63316. doi:10.1371/journal.pone.0063316

Diop, L., Guillou, S., \& Durand, H. (2008). Probiotic food supplement reduces stress-induced gastrointestinal symptoms in volunteers: A double-blind, placebo-controlled, randomized trial. Nutrition Research, 28, 1-5. doi:10.1016/j .nutres.2007.10.001

Donoghue, J. P. (2002). Connecting cortex to machines: Recent advances in brain interfaces. Nature Neuroscience, 5(Suppl.), 1085-1088. doi:10.1038/nn947

Elahi, S., Ertelt, J. M., Kinder, J. M., Jiang, T. T., Zhang, X., Xin, L., ... Way, S. S. (2013, December 5). Immunosuppressive CD71+ erythroid cells compromise neonatal host defense against infection. Nature, 504, 158-162. doi:10.1038/ nature12675

Emera, D., Romero, R., \& Wagner, G. (2012). The evolution of menstruation: A new model for genetic assimilation: Explaining molecular origins of maternal responses to fetal invasiveness. BioEssays, 34, 2635. doi:10.1002/ bies.201100099

Fabiani, S., Pinto, B., \& Bruschi, F. (2013). Toxoplasmosis and neuropsychiatric diseases: Can serological studies establish a clear relationship? Neurological Sciences, 34, 417-425. doi:10.1007/s10072-0121197-4

Finsterer, J., \& Auer, H. (2013). Parasitoses of the human central nervous system. Journal of Helminthology, 87, 257-270. doi:10.1017/S0022149X12000600

Flannery, K. A., \& Liederman, J. (1994). A test of the immunoreactive theory of the origin of neurodevelopmental disorders: Is there an antecedent brother effect? Developmental Neuropsychology, $10,481-492$.

Flegr, J. (2013). How and why Toxoplasma makes us crazy. Trends in Parasitology, 29, 156-163. doi:10.1016/j. pt.2013.01.007 
Flegr, J., Prandota, J., Sovic `ovová, M., \& Israili, Z. H. (2014). Toxoplasmosis-A global threat. Correlation of latent Toxoplasmosis with specific disease burden in a set of 88 countries. PLoS ONE, 9(3), e90203. doi:10.1371/journal .pone.0090203

Fowden, A. L., Coan, P. M., Angiolini, E., Burton, G. J., \& Constancia, M. (2011). Imprinted genes and the epigenetic regulation of placental phenotype. Progress in Biophysics \& Molecular Biology, 106, 281-288. doi:10.1016/j .pbiomolbio.2010.11.005

Frank, O., Jones-Brando, L., Leib-Mosch, C., Yolken, R., \& Seifarth, W. (2006). Altered transcriptional activity of human endogenous retroviruses in neuroepithelial cells after infection with Toxoplasma gondii. Journal of Infectious Diseases, 194, 1447-1449. doi:10.1086/508496

Funkhouser, L. J., \& Bordenstein, S. R. (2013). Mom knows best: The universality of maternal microbial transmission. PLoS Biology, 11(8), e1001631. doi:10.1371/journal.pbio.1001631

Furness, J. B. (2006). The enteric nervous system. Oxford, England: Blackwell.

Gangopadhyay, A. N., Srivastava, A., Srivastava, P., Gupta, D. K., Sharma, S. P., \& Kumar, V. (2010). Twin fetus in fetu in a child: A case report and review of the literature. Journal of Medical Case Reports, 4, Article 96. doi:10.1186/1752-1947- 4-96

Gaskell, E. A., Smith, J. E., Pinney, J. W., Westhead, D. R., \& McConkey, G. A. (2009). A unique dual activity amino acid hydroxylase in Toxoplasma gondii. PLoS ONE, 4(3), e4801. doi:10.1371/journal.pone.0004801

Gilman, S. R., Chang, J., Xu, B., Bawa, T. S., Gogos, J. A., Karayiorgou, M., \& Vitkup, D. (2012). Diverse types of genetic variation converge on functional gene networks involved in schizophrenia. Nature Neuroscience, 15, 1723- 1728. doi:10.1038/nn.3261

Gimelbrant, A., Hutchinson, J. N., Thompson, B. R., \& Chess, A. (2007, November 16). Widespread monoallelic expression on human autosomes. Science, 318, 1136-1140. doi:10.1126/science.1148910

Gough, E., Shaikh, H., \& Manges, A. R. (2011). Systematic review of intestinal microbiota transplantation (fecal bacteriotherapy) for recurrent Clostridium difficile infection. Clinical Infectious Diseases, 53, 9941002. doi:10.1093/cid/ cir632

Gray, S. J. (2013). Gene therapy and neurodevelopmental disorders. Neuropharmacology, 68, 136-142. doi:10.1016/j. neuropharm.2012.06.024

Gregg, C., Zhang, J., Butler, J. E., Haig, D., \& Dulac, C. (2010, August 6). Sex-specific parent-of-origin allelic expression in the mouse brain. Science, 329, 682-685. doi:10.1126/ science.1190831

Gregg, C., Zhang, J., Weissbourd, B., Luo, S., Schroth, G. P., Haig, D., \& Dulac, C. (2010, August 6). Highresolution analysis of parent-of-origin allelic expression in the mouse brain. Science, 329, 643-648. doi:10.1126/science.1190830

Gros, D. F., Antony, M. M., McCabe, R. E., \& Swinson, R. P. (2009). Frequency and severity of the symptoms of irritable bowel syndrome across the anxiety disorders and depression. Journal of Anxiety Disorders, 23, 290-296. doi:10.1016/j.janxdis.2008.08.004

Gualtieri, T., \& Hicks, R. E. (1985). An immunoreactive theory of selective male affliction. Behavioral \& Brain Sciences, 8, 427-441.

Haig, D. (1993). Genetic conflicts in human pregnancy. Quarterly Review of Biology, 4, 495-532.

Haig, D. (2002). Genomic imprinting and kinship. New Brunswick, NJ: Rutgers University Press.

Haig, D. (2011). Genomic imprinting and the evolutionary psychology of human kinship. Proceedings of the National Academy of Sciences, USA, 108 (Suppl. 2), 10878-10885. doi:10.1073/pnas.1100295108

Haig, D. (2012). Retroviruses and the placenta. Current Biology, 22(15), R609-R613. doi:10.1016/j.cub.2012.06.002

Hoover, K., Grove, M., Gardner, M., Hughes, D. P., McNeil, J., \& Slavicek, J. (2011, September 9). A gene for an extended phenotype. Science, 333, 1401.

Hsu, P.-C., Groer, M., \& Beckie, T. (2014). New findings: Depression, suicide, and Toxoplasma gondii infection. Journal of the American Association of Nurse Practitioners, 26, 629-637. doi:10.1002/23276924.12129

Hughes, J. R. (2010). A review of savant syndrome and its possible relationship to epilepsy. Epilepsy \& Behavior, 17, 147- 152. doi:10.1016/j.yebeh.2009.12.014

Hurley, R. A., \& Taber, K. H. (2012). Latent Toxoplasmosis gondii: Emerging evidence for influences on neuropsychiatric disorders. Journal of Neuropsychiatry and Clinical Neurosciences, 24, 376-383. doi:10.1176/appi.neuropsych.12100234

Ishida, M., \& Moore, G. E. (2013). The role of imprinted genes in humans. Molecular Aspects of Medicine, 34, 826-840

Jones-Brando, L., Torrey, E. F., \& Yolken, R. (2003). Drugs used in the treatment of schizophrenia and bipolar disorder inhibit the replication of Toxoplasma gondii. Schizophrenia Research, 62, 237-244.

Kantrowitz, J. T., \& Javitt, D. C. (2010). N-methyl-d-aspartate (NMDA) receptor dysfunction or dysregulation: The final common pathway on the road to schizophrenia? Brain Research Bulletin, 83, 108-121.

Kent, L., Bowdin, S., Kirby, G. A., Cooper, W. N., \& Maher, E. R. (2008). Beckwith-Wiedemann syndrome: A behavioral phenotype-genotype study. American Journal of Medical Genetics, Part B: Neuropsychiatric Genetics, 147B, 1295- 1297. doi:10.1002/ajmg.b.30729

Keverne, E. B. (2013). Importance of the matriline for genomic imprinting, brain development and behaviour. Philosophical Transactions of the Royal Society B: Biological Sciences, 368, 20110327. 
doi:10.1098/rstb.2011.0327

Keverne, E. B., \& Curley, J. P. (2008). Epigenetics, brain evolution and behaviour. Frontiers in Neuroendocrinology, 29, 398-412. doi:10.1016/j.yfrne.2008.03.001

Klar, A. J. (2004). An epigenetic hypothesis for human brain laterality, handedness, and psychosis development. Cold Spring Harbor Symposia on Quantitative Biology, 69, 499- 506. doi:10.1101/sqb.2004.69.499

Kopsida, E., Mikaelsson, M. A., \& Davies, W. (2011). The role of imprinted genes in mediating susceptibility to neuropsychiatric disorders. Hormones and Behavior, 59, 375-382. doi:10.1016/j.yhbeh.2010.04.005

Kortbeek, L. M. (1999). Parasitologie-Toxoplasmose in Nederland [Parasitology-Toxoplasmosis in the Netherlands]. Nederlands Tijdschrift Voor Klinische Chemie, 24, 65-70.

Lander, E. S., Linton, L. M., Birren, B., Nusbaum, C., Zody, M. C., Baldwin, J., . . International Human Genome Sequencing Consortium. (2001, February 15). Initial sequencing and analysis of the human genome. Nature, 409, 860-921. doi:10.1038/35057062

Lavialle, C., Cornelis, G., Dupressoir, A., Esnault, C., Heidmann, O., Vernochet, C., \& Heidmann, T. (2013). Paleovirology of "syncytins," retroviral env genes exapted for a role in placentation. Philosophical Transactions of the Royal Society B: Biological Sciences, 368, 1471-2970. doi:10.1098/rstb.2012.0507

Leboyer, M., Tamouza, R., Charron, D., Faucard, R., \& Perron, H. (2013). Human endogenous retrovirus type W (HERV-W) in schizophrenia: A new avenue of research at the gene-environment interface. World Journal of Biological Psychiatry, 14(2), 80-90. doi:10.3109/15622975.2010.601760

Lee, J. T., \& Bartolomei, M. S. (2013). X-inactivation, imprinting, and long noncoding RNAs in health and disease. Cell, 152, 1308-1323. doi:10.1016/j.cell.2013.02.016

Lee, S. H., Ripke, S., Neale, B. M., Faraone, S. V., Purcell, S. M., \& Perlis, R. H., . . Cross-Disorder Group of the Psychiatric Genomics Consortium. (2013). Genetic relationship between five psychiatric disorders estimated from genomewide SNPs. Nature Genetics, 45, 984-994.

Lentz, T. B., Gray, S. J., \& Samulski, R. J. (2012). Viral vectors for gene delivery to the central nervous system. Neurobiology of Disease, 48, 179-188. doi:10.1016/j.nbd.2011.09.014

LeWitt, P. A., Rezai, A. R., Leehey, M. A., Ojemann, S. G., Flaherty, A. W., Eskandar, E. N., .. Feigin, A. (2011). AAV2-GAD gene therapy for advanced Parkinson's disease: A double-blind, sham-surgery controlled, randomised trial. Lancet Neurology, 10, 309-319. doi:10.1016/S1474-4422(11)70039-4

Ley, R. E., Peterson, D. A., \& Gordon, J. I. (2006). Ecological and evolutionary forces shaping microbial diversity in the human intestine. Cell, 124, 837-848. doi:10.1016/ j.cell.2006.02.017

Lizko, N. N. (1987). Stress and intestinal microflora. Food/Nahrung, 31, 443-447.

Louis, P. (2012). Does the human gut microbiota contribute to the etiology of autism spectrum disorders? Digestive Diseases and Sciences, 57, 1987-1989.

Lyte, M., Varcoe, J. J., \& Bailey, M. T. (1998). Anxiogenic effect of subclinical bacterial infection in mice in the absence of overt immune activation. Physiology \& Behavior, 65, 63-68.

Magiorkinis, G., Belshaw, R., \& Katzourakis, A. (2013). 'There and back again': Revisiting the pathophysiological roles of human endogenous retroviruses in the post-genomic era. Philosophical Transactions of the Royal Society B: Biological Sciences, 368, 20120504. doi:10.1098/rstb.2012.0504

Martin, L. A., Ashwood, P., Braunschweig, D., Cabanlit, M., Van de Water, J., \& Amaral, D. G. (2008). Stereotypies and hyperactivity in rhesus monkeys exposed to igG from mothers of children with autism. Brain, Behavior, and Immunity, 22, 806-816. doi:10.1016/j.bbi.2007.12.007

McConkey, G. A., Martin, H. L., Bristow, G. C., \& Webster, J. P. (2013). Toxoplasma gondii infection and behaviour - location, location, location? Journal of Experimental Biology, 216(Pt. 1), 113-119. doi:10.1242/jeb.074153

McLaren, A., Simpson, E., Tomonari, K., Chandler, P., \& Hogg, H. (1984, December 6-12). Male sexual differentiation in mice lacking H-Y antigen. Nature, 312, 552-555.

Mertz, L. G., Thaulov, P., Trillingsgaard, A., Christensen, R., Vogel, I., Hertz, J. M., \& Ostergaard, J. R. (2014). Neurodevelopmental outcome in Angelman syndrome: Genotype-phenotype correlations. Research in Developmental Disabilities, 35, 1742-1747. doi:10.1016/ j.ridd.2014.02.018

Messaoudi, M., Lalonde, R., Violle, N., Javelot, H., Desor, D., Nejdi, A., .. Cazaubiel, J. M. (2011). Assessment of psychotropic-like properties of a probiotic formulation (lactobacillus helveticus R0052 and bifidobacterium longum R0175) in rats and human subjects. British Journal of Nutrition, 105, 755-764. doi:10.1017/S0007114510004319

Mi, S., Lee, X., Li, X., Veldman, G. M., Finnerty, H., Racie, L., .. McCoy, J. M. (2000, February 17). Syncytin is a captive retroviral envelope protein involved in human placental morphogenesis. Nature, 403, 785-789. doi:10.1038/35001608

Müller, N., Myint, A. M., \& Schwarz, M. J. (2011). Kynurenine pathway in schizophrenia: Pathophysiological and therapeutic aspects. Current Pharmaceutical Design, 17, 130-136.

Nellåker, C., Yao, Y., Jones-Brando, L., Mallet, F., Yolken, R. H., \& Karlsson, H. (2006). Transactivation of elements in the human endogenous retrovirus W family by viral infection. Retrovirology, 3, Article 44. doi:10.1186/1742-4690-3-44

Neufeld, K. M., Kang, N., Bienenstock, J., \& Foster, J. A. (2011). Reduced anxiety-like behavior and central neurochemical change in germ-free mice. Neurogastroenterology \& Motility, 23, 255-264. e119. doi:10.1111/j.1365-2982.2010.01620.x

Niebuhr, D. W., Millikan, A. M., Cowan, D. N., Yolken, R., Li, Y. Z., \& Weber, N. S. (2008). Selected infectious 
agents and risk of schizophrenia among U.S. military personnel. American Journal of Psychiatry, 165, 99106.

Norbury, A., Manohar, S., Rogers, R. D., \& Husain, M. (2013). Dopamine modulates risk-taking as a function of baseline sensation-seeking trait. Journal of Neuroscience, 33, 12982-12986. doi:10.1523/JNEUROSCI.5587-12.2013

Pae, C. U., Marks, D. M., Han, C., \& Patkar, A. A. (2008). Does minocycline have antidepressant effect? Biomedicine \& Pharmacotherapy, 62, 308-311. doi:10.1016/j.biopha .2007.12.005

Palmer, C., Bik, E. M., DiGiulio, D. B., Relman, D. A., \& Brown, P. O. (2007). Development of the human infant intestinal microbiota. PLoS Biology, 5(7), e177. doi:10.1371/journal. pbio.0050177

Paulus, M. P., \& Stein, M. B. (2006). An insular view of anxiety. Biological Psychiatry, 60, 383-387. doi:10.1016/j.biopsych. 2006.03.042

Perron, H., Hamdani, N., Faucard, R., Lajnef, M., Jamain, S., Daban-Huard, C., . . Leboyer, M. (2012). Molecular characteristics of human endogenous retrovirus type-W in schizophrenia and bipolar disorder. Translational Psychiatry, 2, e201. doi:10.1038/tp.2012.125

Prandovszky, E., Gaskell, E., Martin, H., Dubey, J. P., Webster, J. P., \& McConkey, G. A. (2011). The neurotropic parasite Toxoplasma gondii increases dopamine metabolism. PLoS ONE, 6(9), e23866. doi:10.1371/journal.pone.0023866

Qin, J., Li, R., Raes, J., Arumugam, M., Burgdorf, K. S., Manichanh, C., ... Wang, J. (2010, March 4). A human gut microbial gene catalogue established by metagenomic sequencing. Nature, 464, 59-65. doi:10.1038/nature08821

Ramirez, P. L., Barnhill, K., Gutierrez, A., Schutte, C., \& Hewitson, L. (2013). Improvements in behavioral symptoms following antibiotic therapy in a 14-year-old male with autism. Case Reports in Psychiatry, 2013, 239034. doi:10.1155/2013/239034

Rao, A. V., Bested, A. C., Beaulne, T. M., Katzman, M. A., Iorio, C., Berardi, J. M., \& Logan, A. C. (2009). A randomized, double-blind, placebo-controlled pilot study of a probiotic in emotional symptoms of chronic fatigue syndrome. Gut Pathogens, 1(1), Article 6. doi:10.1186/1757-4749-1-6

Sandler, R. H., Finegold, S. M., Bolte, E. R., Buchanan, C. P., Maxwell, A. P., Väisänen, M.-L., ... Wexler, H. M. (2000). Short-term benefit from oral vancomycin treatment of regressive-onset autism. Journal of Child Neurology, 15, 429-435.

Seckl, J. R., \& Holmes, M. C. (2007). Mechanisms of disease: Glucocorticoids, their placental metabolism and fetal 'programming' of adult pathophysiology. Nature Clinical Practice Endocrinology \& Metabolism, 3, 479-488. doi:10.1038/ncpendmet0515

Severance, E. G., Alaedini, A., Yang, S., Halling, M., Gressitt, K. L., Stallings, C. R., . . Yolken, R. H. (2012). Gastrointestinal inflammation and associated immune activation in schizophrenia. Schizophrenia Research, 138, 48-53. doi:10.1016/j. schres.2012.02.02

Shanks, N., Windle, R. J., Perks, P. A., Harbuz, M. S., Jessop, D. S., Ingram, C. D., \& Lightman, S. L. (2000). Earlylife exposure to endotoxin alters hypothalamic-pituitary-adrenal function and predisposition to inflammation. Proceedings of the National Academy of Sciences, USA, 97, 5645-5650.

Shultz, S. R., MacFabe, D. F., Ossenkopp, K.-P., Scratch, S., Whelan, J., Taylor, R., \& Cain, D. P. (2008). Intracerebroventricular injection of propionic acid, an enteric bacterial metabolic end-product, impairs social behavior in the rat: Implications for an animal model of autism. Neuropharmacology, 54, 901-911.

Simanek, A. M., Dowd, J. B., Pawelec, G., Melzer, D., Dutta, A., \& Aiello, A. E. (2011). Seropositivity to cytomegalovirus, inflammation, all-cause and cardiovascular disease-related mortality in the United States. PLoS ONE, 6(2), e16103. doi:10.1371/journal.pone.0016103

Simonato, M., Bennett, J., Boulis, N. M., Castro, M. G., Fink, D. J., Goins, W. F., . . Glorioso, J. C. (2013). Progress in gene therapy for neurological disorders. Nature Reviews Neurology, 9, 277-291. doi:10.1038/nrneurol.2013.56

Soczynska, J. K., Mansur, R. B., Brietzke, E., Swardfager, W., Kennedy, S. H., Woldeyohannes, H. O., ... McIntyre, R. S. (2012). Novel therapeutic targets in depression: Minocycline as a candidate treatment. Behavioural Brain Research, 235, 302-317. doi:10.1016/j.bbr.2012.07.026

Song, Y., Liu, C., \& Finegold, S. M. (2004). Real-time PCR quantification of clostridia in feces of autistic children. Applied Environmental Microbiology, 70, 6459-6465.

Staras, S. A., Dollard, S. C., Radford, K. W., Flanders, W. D., Pass, R. F., \& Cannon, M. J. (2006). Seroprevalence of cytomegalovirus infection in the United States, 1988-1994. Clinical Infectious Diseases, 43, 11431151.

Sudo, N., Chida, Y., Aiba, Y., Sonoda, J., Oyama, N., Yu, X. N., .. Koga, Y. (2004). Postnatal microbial colonization programs the hypothalamic-pituitary-adrenal system for stress response in mice. Journal of Physiology, 558, 263-275. doi:10.1113/jphysiol.2004.063388

Svarovskaia, E. S., Cheslock, S. R., Zhang, W.-H., Hu, W.-S., \& Pathak, V. K. (2003). Retroviral mutation rates and reverse transcriptase fidelity. Frontiers in Bioscience, 8, d117-d134.

Swaney, W. T. (2011). Genomic imprinting and mammalian reproduction. Hormones and Behavior, 59, 369374.

Tenter, A. M., Heckeroth, A. R., \& Weiss, L. M. (2000). Toxoplasma gondii: From animals to humans. International Journal for Parasitology, 30, 1217-1258.

Thomas, F., Daoust, S. P., \& Raymond, M. (2012). Can we understand modern humans without considering pathogens? Evolutionary Applications, 5, 368-379. doi:10.1111/ j.1752-4571.2011.00231.x 
Tillisch, K., Labus, J., Kilpatrick, L., Jiang, Z., Stains, J., Ebrat, B., ... Mayer, E. A. (2013). Consumption of fermented milk product with probiotic modulates brain activity. Gastroenterology, 144, 1394-1401., 1401.e1-4. doi:10.1053/j. gastro.2013.02.043

Todman, D. (2007). Childbirth in ancient Rome: From traditional folklore to obstetrics. Australian and New Zealand Journal of Obstetrics and Gynaecology, 47, 82-85. doi:10.1111/ j.1479-828X.2007.00691.x

Torrey, E. F., Bartko, J. J., Lun, Z. R., \& Yolken, R. H. (2007). Antibodies to Toxoplasma gondii in patients with schizophrenia: A meta-analysis. Schizophrenia Bulletin, 33, 729-736. doi:10.1093/schbul/sbl050

Tuszynski, M. H., Thal, L., Pay, M., Salmon, D. P., U, H. S., Bakay, R., ... Conner, J. U. (2005). A phase 1 clinical trial of nerve growth factor gene therapy for Alzheimer disease. Nature Medicine, 11, 551-555. doi:10.1038/nm1239

Van Dijk, B. A., Boomsma, D. I., \& de Man, A. J. (1996). Blood group chimerism in human multiple births is not rare. American Journal of Medical Genetics, 61, 264-268.

Vincent, A., Deacon, R., Dalton, P., Salmond, C., Blamire, A. M., Pendlebury, S., .. Stein, J. (2002). Maternal antibody-mediated dyslexia? Evidence for a pathogenic serum factor in a mother of two dyslexic children shown by transfer to mice using behavioural studies and magnetic resonance spectroscopy. Journal of Neuroimmunology, 130, 243-247.

Walker, J., Nokes, D. J., \& Jennings, R. (1992). Longitudinal study of Toxoplasma seroprevalence in South Yorkshire. Epidemiology \& Infection, 108, 99-106.

Webb, T., Maina, E. N., Soni, S., Whittington, J., Boer, H., Clarke, D., \& Holland, A. (2008). In search of the psychosis gene in people with Prader-Willi syndrome. American Journal of Medical Genetics A, 146A, 843-853. doi:10.1002/ ajmg.a.32212

Webster, J. P., Kaushik, M., Bristow, G. C., \& McConkey, G. A. (2013). Toxoplasma gondii infection, from predation to schizophrenia: Can animal behaviour help us understand human behaviour? Journal of Experimental Biology, 216(Pt. 1), 99-112. doi:10.1242/jeb.074716

Webster, J. P., Lamberton, P. H., Donnelly, C. A., \& Torrey, E. F. (2006). Parasites as causative agents of human affective disorders? The impact of anti-psychotic, mood-stabilizer and anti-parasite medication on Toxoplasma gondii's ability to alter host behaviour. Proceedings of the Royal Society B: Biological Sciences, 273, 1023-1030. doi:10.1098/ rspb.2005.3413

Whiteley, P., Shattock, P., Knivsberg, A. M., Seim, A., Reichelt, K. L., Todd, L., . . Hooper, M. (2013). Glutenand casein-free dietary intervention for autism spectrum conditions. Frontiers in Human Neuroscience, 6 , Article 344. doi:10.3389/fnhum.2012.00344

Wilkins, J. F., \& Haig, D. (2003). What good is genomic imprinting: The function of parent-specific gene expression. Nature Reviews Genetics, 4, 359-368. doi:10.1038/nrg1062

Williams, C. A., Driscoll, D. J., \& Dagli, A. I. (2010). Clinical and genetic aspects of Angelman syndrome. Genetics in Medicine, 12, 385-395.

Wolf, U., Schempp, W., \& Scherer, G. (1992). Molecular biology of the human Y chromosome. Reviews of Physiology, Biochemistry and Pharmacology, 121, 147-213.

Wonodi, I., \& Schwarcz, R. (2010). Cortical kynurenine pathway metabolism: A novel target for cognitive enhancement in schizophrenia. Schizophrenia Bulletin, 36, 211-218. doi:10.1093/schbul/sbq002

Worth, A. R., Lymbery, A. J., \& Thompson, R. C. A. (2013). Adaptive host manipulation by Toxoplasma gondii: Fact or fiction? Trends in Parasitology, 29, 150-155.

Yehuda, R., Engel, S. M., Brand, S. R., Seckl, J., Marcus, S. M., \& Berkowitz, G. S. (2005). Transgenerational effects of posttraumatic stress disorder in babies of mothers exposed to the World Trade Center attacks during pregnancy. Journal of Clinical Endocrinology and Metabolism, 90, 4115-4118. doi:10.1210/jc.2005-0550

Yu, N., Kruskall, M. S., Yunis, J. J., Knoll, J. H., Uhl, L., Alosco, S., .. Yunis, E. J. (2002). Disputed maternity leading to identification of tetragametic chimerism. New England Journal of Medicine, 346, 1545-1552. doi:10.1056/ 